\title{
ANALISIS KESULITAN BELAJAR KIMIA SISWA PADA MATERI KELARUTAN DAN HASIL KALI KELARUTAN
}

\author{
I Ketut Sudiana; I Wayan Suja; Irma Mulyani
}

Universitas Pendidikan Ganesha

\author{
A R T I C L E I N F O \\ Article history: Received 8 \\ Januari 2019 Received in \\ revised form 14 Januari 2019 \\ Accepted 12 Maret 2019 \\ Available online 30 April \\ 2019
}

Kata Kunci: kesulitan belajar, kelarutan dan hasil kali kelarutan

\begin{abstract}
Abstrak
Penelitian ini bertujuan mendeskripsikan dan menjelaskan kesulitan belajar siswa dan faktor-faktor penyebab kesulitan belajar siswa dalam mempelajari materi kelarutan dan hasil kali kelarutan. Subjek penelitian adalah 38 orang siswa dari seluruh kelas XII IPA. Metode penelitian yang digunakan adalah mixed method. Pengambilan data dilakukan dengan cara observasi, tes, dan wawancara. Analisis data yang dilakukan adalah analisis hasil observasi, analisis hasil tes diagnostik dan analisis hasil wawancara. Data yang diperoleh berupa hasil belajar siswa dan informasi mengenai faktor-faktor penyebab kesulitan belajar siswa pada materi kelarutan dan hasil kali kelarutan. Hasil penelitian menunjukkan bahwa bentuk kesulitan belajar siswa pada materi kelarutan dan hasil kali kelarutan adalah pemahaman materi prasayarat, menuliskan ionisasi garam, penggunaan rumus Ksp, pemahaman siswa pada konsep asam basa, pemahaman siswa pada konsep kesetimbangan kimia, pemahaman siswa pada penulisan persamaan reaksi, dan kemampuan operasi matematika. Faktor-faktor penyebab kesulitan belajar siswa yang disebabkan oleh faktor internal, meliputi: minat belajar kimia rendah, motivasi belajar kimia rendah, pemaknaan konsep siswa terhadap materi kelarutan dan hasil kali kelarutan rendah, pemahaman konsep prasyarat materi kelarutan dan hasil kali kelarutan rendah, dan kemampuan siswa dalam operasi matematika yang lemah. Faktor eksternal, meliputi: pengaruh negatif dari teman sebaya dan cara mengajar guru.
\end{abstract}

\begin{abstract}
This study aims to describe and explain student learning difficulties and the factors that cause students' learning difficulties in learning the material solubility and solubility results. The research subjects were 38 students from all XII IPA classes. The research method used is a mixed method. Data retrieval is done by observation, tests, and interviews. Data analysis was carried out by analyzing the results of observations, analyzing the results of diagnostic tests and analyzing the results of interviews. Data obtained in the form of student learning outcomes and information about the factors that cause student learning difficulties in the material solubility and solubility results. The results showed that the form of student learning difficulties in the solubility and solubility results material was understanding pre-set material, writing salt ionization, using Ksp formula, understanding students on the concept of acid base, understanding students in the concept of chemical equilibrium, understanding students in writing equation, and mathematical operating abilities. Factors that cause student learning difficulties caused by internal factors include: low chemistry learning interest, low chemistry learning motivation, meaning of students' concept of solubility and low solubility products, understanding the concept of solubility material and low solubility results, and ability students in weak mathematical operations. External factors include: negative influence from peers and how to teach teachers.
\end{abstract}

Keywords: learning difficulties, solubility and solubility results 


\section{PENDAHULUAN}

Kimia merupakan materi yang dianggap paling sulit oleh sebagian besar siswa SMA. Hal ini ditunjukan dengan hasil belajar siswa yang relatif rendah pada pelajaran kimia. Fenomena hasil belajar yang rendah pada pelajaran kimia tidak hanya terjadi di satu sekolah, namun terjadi di beberapa sekolah yang ada di Singaraja. Hasil belajar yang rendah mengindikasikan bahwa terjadi kesulitan belajar yang dialami oleh siswa, tapi belum jelas bentuk kesulitan yang dialami. Untuk mengetahui secara jelas bentuk kesulitannya, perlu dilakukan diagnosis kesulitan belajar serta faktor-faktor penyebab kesulitan belajar tersebut.

Kesulitan yang dialami siswa dalam mempelajari kelarutan dan hasil kali kelarutan didukung oleh penelitian Hidayah (2013), yang menyatakan bahwa masih banyak siswa belum memahami konsep prasyarat, seperti konsep mol, reaksi ionisasi, kesetimbangan kimia, pH larutan asam dan basa, serta kesulitan dalam menghubungkan antar konsep. Kesulitan siswa juga dikarenakan kurangnya guru memberikan contoh-contoh tentang reaksi-reaksi yang ada di lingkungan sekitar yang sering dijumpai siswa. Penelitian Ulfa (2016) menemukan hasil bahwa sebagian besar siswa-siswi pada SMA Inshafuddin mengalami kesulitan dalam memahami konsep kelarutan dan hasil kali kelarutan. Rata-rata siswa tidak memahami hampir seluruh konsep yang diujiankan. Hal ini disebabkan oleh beberapa faktor, diantaranya faktor yang berasal dari diri siswa dan faktor dari guru atau lingkungan.

Menurut Dalyono (2007) kesulitan belajar siswa disebabkan oleh faktor internal dan faktor eksternal. Faktor internal meliputi ranah kognitif, afektif, dan psikomotorik. Sedangkan, faktor eksternal siswa meliputi lingkungan keluarga, masyarakat, dan sekolah. Menurut Slameto (2003), faktor yang termasuk ke dalam faktor internal meliputi faktor jasmaniah (faktor kesehatan dan cacat tubuh) dan faktor psikologis (intelegensi, perhatian, minat, bakat, motif, kematangan, dan kesiapan). Faktor eksternal meliputi keadaan keluarga (cara orang tua mendidik, relasi antar anggota keluarga, suasana rumah, keadaan ekonomi keluarga, perhatian orang tua, dan latar belakang kebudayaan), faktor sekolah (metode mengajar guru, kurikulum, relasi guru dengan siswa, relasi siswa dengan siswa, disiplin sekolah, alat pelajaran, waktu pelajaran, dan keadaan gedung), serta faktor masyarakat (kegiatan siswa dalam masyarakat, teman bergaul, dan bentuk kehidupan di masyarakat).

Salah satu indikator adanya kesulitan belajar pada siswa adalah rendahnya hasil belajar yang diperoleh. Hasil observasi awal peneliti di SMAN 1 Sukasada menunjukan bahwa nilai hasil belajar kelarutan dan hasil kali kelarutan tergolong rendah. Hal tersebut dinyatakan oleh guru kimia dan didukung nilai hasil ulangan harian siswa pada materi tersebut. Sebagian besar siswa memiliki nilai di bawah KKM yang ditetapkan, yaitu 75 dan hanya 5\% siswa mencapai KKM dikarenakan kurangnya minat siswa dalam mempelajari kimia sehingga mereka mengalami kesulitan dalam menyelesaikan permasalahan mengenai kelarutan dan hasil kali kelarutan.

Berdasarkan permasalahan di atas dapat diketahui bahwa kesulitan belajar kimia, termasuk pada materi kelarutan dan hasil kali kelarutan merupakan fenomena umum yang terjadi di sekolah-sekolah. Oleh karena itu, perlu dilakukan diagnosis kesulitan belajar dengan menggunakan tes diagnostik sebagai upaya untuk memahami bentuk dan latar belakang kesulitan-kesulitan belajar karena kesulitan belajar merupakan salah satu penghambat keberhasilan belajar. Atas dasar itu, penulis tertarik dalam melakukan penelitian mengenai "Analisis Kesulitan Belajar Kimia Siswa pada Materi Kelarutan dan Hasil Kali Kelarutan di SMAN 1 Sukasada".

\section{METODE PENELITIAN}

Jenis penelitian yang digunakan dalam penelitian ini adalah penelitian mixed method dengan pendekatan fenomenologi. Pada penelitian ini, pengalaman yang ingin digambarkan dan diinterpretasikan adalah kesulitan belajar kimia siswa pada materi kelarutan dan hasil kali kelarutan.

Penelitian tentang analisis kesulitan belajar kimia siswa pada materi kelarutan dan hasil kali kelarutan ini dilaksanakan di SMA Negeri 1 Sukasada. Penelitian dilaksanakan pada semester ganjil tahun ajaran 2018/2019. Pelaku pada penelitian ini adalah seluruh siswa pada kelas XII MIPA di SMA Negeri 1 Sukasada yang berjumlah 38 orang dan telah melewati proses pembelajaran pada materi kelarutan dan hasil kali kelarutan. Aktivitas yang ingin diteliti dalam penelitian ini adalah kesulitan belajar kimia dalam mempelajari materi kelarutan dan hasil kali kelarutan dan faktor penyebab kesulitan belajar kimia siswa pada materi kelarutan dan hasil kali kelarutan.

Instrumen penelitian yang digunakan adalah tes hasil belajar kelarutan dan hasil kali kelarutan yang berupa pedoman observasi, tes pilihan ganda beralasan, dan pedoman wawancara. Tes pilihan ganda beralasan berjumlah 15 soal dengan karakteristik soal valid dengan rentangan $r_{b i s}$ yang diperoleh sebesar $0,26-0,81$. Soal memiliki reliabilitas tinggi dengan nilai reliabilitas sebesar 0,739. 
Teknik analisis data yang digunakan pada penelitian ini meliputi analisis statistika deskriptif. Teknik analisis statistika deskriptif digunakan untuk menganalisis data berupa nilai tes hasil belajar siswa dan teknik analisis deskriptif interpretatif digunakan untuk menganalisis data hasil observasi dan wawancara.

\section{HASIL ANALISIS DATA}

Berdasarkan nilai yang diperoleh siswa, kemudian dibuat kriteria untuk mengelompokkan siswa ke dalam kelompok siswa atas, kelompok siswa menengah, dan kelompok siswa bawah. Kriteria ini dibuat berdasarkan nilai siswa, dapat dilihat pada Tabel 01.

Tabel 01. Jumlah Siswa Kelompok Atas, Menengah, dan Bawah

\begin{tabular}{lcc}
\hline \multicolumn{1}{c}{ Kriteria } & $\begin{array}{c}\text { Jumlah } \\
\text { Siswa }\end{array}$ & $\begin{array}{c}\text { Persentase } \\
\text { (\%) }\end{array}$ \\
\hline Kelompok Atas & 3 orang & 7,69 \\
Kelompok Menengah & 17 orang & 43,59 \\
Kelompok Bawah & 19 orang & 48,72 \\
\hline
\end{tabular}

Berdasarkan data hasil penelitian, kelompok atas sebanyak 7,69\%, kelompok menegah 43,59\%, dan kelompok bawah 48,72\%. Nilai KKM pelajaran kimia di SMAN 1 Sukasada adalah 75. Nilai tes hasil belajar kelarutan dan hasil kali kelarutan menunjukkan bahwa 92,3\% siswa mendapat nilai di bawah KKM.

Materi kelarutan dan hasil kali kelarutan terdiri atas tujuh indikator, yaitu (1) menyebutkan faktorfaktor yang mempengaruhi kelarutan suatu zat, (2) menghubungkan tetapan hasil kali kelarutan dengan tingkat kelarutan atau pengendapannya, (3) menuliskan ungkapan berbagai Ksp elektrolit yang sukar larut dalam air, (4) menghitung kelarutan suatu elektrolit yang sukar larut berdasarkan data harga Ksp dan pHnya atau sebaliknya, (5) menjelaskan pengaruh penambahan ion senama terhadap kelarutan, (6) menentukan pH larutan dari harga Ksp atau kelarutannya, dan (7) memperkirakan terbentuknya endapan berdasarkan harga Ksp. Kesulitan belajar siswa pada tiap indikator ditentukan berdasarkan jumlah kesalahan pada tiap soal yang mengacu pada indikator tersebut. Jumlah kesalahan kemudian dikonversi menjadi persentase kesulitan belajar siswa. Rincian tingkat kesulitan siswa dapat dilihat pada Tabel 02.

Tabel 02. Tingkat kesulitan siswa pada masing-masing indikator

\begin{tabular}{|c|c|c|c|c|c|c|}
\hline $\begin{array}{l}\text { No. } \\
\text { (1) }\end{array}$ & $\begin{array}{c}\text { Indikator } \\
\text { (2) }\end{array}$ & $\begin{array}{c}\text { No. soal } \\
\text { (3) }\end{array}$ & $\begin{array}{c}\text { KB (\%) } \\
\text { (4) }\end{array}$ & $\begin{array}{c}\text { KKBS } \\
\text { (5) }\end{array}$ & $\begin{array}{c}\text { KBR (\%) } \\
\text { (6) }\end{array}$ & $\begin{array}{c}\text { KKBI } \\
\text { (7) }\end{array}$ \\
\hline 1. & $\begin{array}{l}\text { Menyebutkan faktor-faktor } \\
\text { yang mempengaruhi kelarutan } \\
\text { suatu zat. }\end{array}$ & 1 & 92 & SS & 92 & SS \\
\hline 2. & $\begin{array}{lr}\text { Menghubungkan } & \text { tetapan } \\
\text { hasilkali kelarutan } & \text { dengan } \\
\text { tingkat kelarutan } & \text { atau } \\
\text { pengendapannya. } & \end{array}$ & 2 & $\begin{array}{l}87 \\
21\end{array}$ & SS & 54 & CS \\
\hline 3. & $\begin{array}{l}\text { Menuliskan ungkapan } \\
\text { berbagai Ksp elektrolit yang } \\
\text { sukar larut dalam air. }\end{array}$ & 4 & 95 & $\mathrm{TS}$ & 54,5 & CS \\
\hline 4. & $\begin{array}{l}\text { Menghitung kelarutan suatu } \\
\text { elektrolit yang sukar larut } \\
\text { berdasarkan data harga Ksp } \\
\text { dan pHnya atau sebaliknya. }\end{array}$ & 6 & 56 & CS & 56 & CS \\
\hline 5. & $\begin{array}{l}\text { Menjelaskan ion } \\
\text { penambahan senama } \\
\text { terhadap kelarutan. }\end{array}$ & 7 & 96 & SS & 96 & SS \\
\hline
\end{tabular}


6. Menentukan pH larutan dari

8

56,4

CS

64,2

S

harga Ksp atau kelarutannya.

7. Memperkirakan terbentuk nya

Ksp.

Keterangan:

KB : Kesulitan belajar

KKBS : Kesulitan belajar tiap soal

KBR : Kesulitan belajar rata-rata

KKBI : Kesulitan belajar tiap indikator

SS : Sangat sulit

CS : Cukup sulit

$\mathrm{S} \quad$ : sulit

TS : Tidak sulit

Bentuk kesulitan yang dialami siswa dalam mempelajari materi kelarutan dan hasil kali kelarutan dapat diamati dari jawaban tes hasil belajar siswa. Bentuk-bentuk kesulitan yang dialami siswa dalam mempelajari materi kelarutan dan hasil kali kelarutan dikelompokkan berdasarkan indikator pada materi kelarutan dan hasil kali kelarutan. Rangkuman deskripsi kesulitan belajar kelarutan dan hasil kali kelarutan dapat dilihat pada Tabel 03.

Tabel 03. Rangkuman Deskripsi Kesulitan Belajar

\begin{tabular}{|c|c|c|c|}
\hline No. & Indikator & TK & Bentuk kesulitan \\
\hline 1. & $\begin{array}{l}\text { Menyebutkan faktor yang } \\
\text { mempengaruhi kelarutan } \\
\text { suatu zat. }\end{array}$ & SS & $\begin{array}{l}\text { a. Kesalahan dalam menentukan faktor } \\
\text { yang tidak mempengaruhi kelarutan } \\
\text { suatu zat. } \\
\text { b. Kurang memahami konsep secara } \\
\text { utuh. }\end{array}$ \\
\hline 2. & $\begin{array}{l}\text { Menghubungkan tetapan } \\
\text { hasilkali kelarutan dengan } \\
\text { tingkat kelarutan atau } \\
\text { pengendapannya. }\end{array}$ & $\mathrm{CS}$ & $\begin{array}{l}\text { a. Kesalahan menuliskan reaksi ionisasi. } \\
\text { b. Kesalahan menggunakan rumus. }\end{array}$ \\
\hline 3. & $\begin{array}{l}\text { Menuliskan ungkapan } \\
\text { berbagai Ksp elektrolit yang } \\
\text { sukar larut dalam air. }\end{array}$ & CS & $\begin{array}{ll}\text { a. Kesalahan dalam menulis persamaan } \\
\text { Ksp. } \\
\text { b. Kesalahan penggunaan rumus Ksp. } \\
\text { c. Kesalahan menulis simbol dari } \\
\text { senyawa garam perak sulfat. } \\
\text { d. Kurang memahami konsep hubungan } \\
\text { kelarutan dengan hasil kali kelarutan. }\end{array}$ \\
\hline 4. & $\begin{array}{l}\text { Menghitung kelarutan suatu } \\
\text { elektrolit yang sukar larut } \\
\text { berdasarkan data harga Ksp } \\
\text { dan pHnya atau sebaliknya. }\end{array}$ & CS & $\begin{array}{l}\text { a. Tidak memahami hubungan } \mathrm{pH} \\
\text { dengan kelarutan basa lemah. } \\
\text { b. Kesalahan dalam menentukan rumus } \\
\text { Ksp. } \\
\text { c. Kelemahan dalam operasi } \\
\text { matematika. }\end{array}$ \\
\hline
\end{tabular}


5. Menjelaskan pengaruh penambahan ion senama terhadap kelarutan.

6. Menentukan $\mathrm{pH}$ larutan dari harga Ksp atau kelarutannya.

7. Memperkirakan terbentuknya endapan berdasarkan harga Ksp. a. Kesalahan dalam merumuskan hubungan antara kelarutan dengan Ksp.

b. Kesalahan dalam menghubungkan nilai pH dengan harga kelarutan.

c. Kurang terampil dalam operasi matematika.

S a. Tidak memahami konsep secara utuh berkaitan dengan konsentrasi ion-ion dari pencampuran dua larutan.

b. Kesalahan dalam menentukan nilai Qc.

c. Kurang terampil dalam operasi matematika.

\section{Keterangan : \\ TK : Tingkat kesulitan \\ SS : Sangat Sulit \\ CS : Cukup sulit \\ S : Sulit}

Faktor yang didapat dari hasil interpretasi deskripsi kesulitan belajar dan informasi hasil wawancara adalah minat belajar kimia siswa rendah, motivasi belajar kimia siswa rendah, pemahaman terhadap konsep-konsep pada materi kelarutan dan hasil kali kelarutan rendah, pemahaman terhadap konsep prasyarat materi larutan penyangga rendah, kemampuan matematika siswa lemah, pengaruh negatif dari teman sebaya, dan metode mengajar yang diterapkan guru. Faktor-faktor ini kemudian digolongkan menjadi faktor internal dan eksternal. Rincian faktor-faktor penyebab kesulitan belajar kelarutan dan hasil kali kelarutan dapat dilihat pada tabel 04.

Tabel 0.4 Rangkuman Deskripsi Faktor Penyebab Kesulitan Belajar Siswa

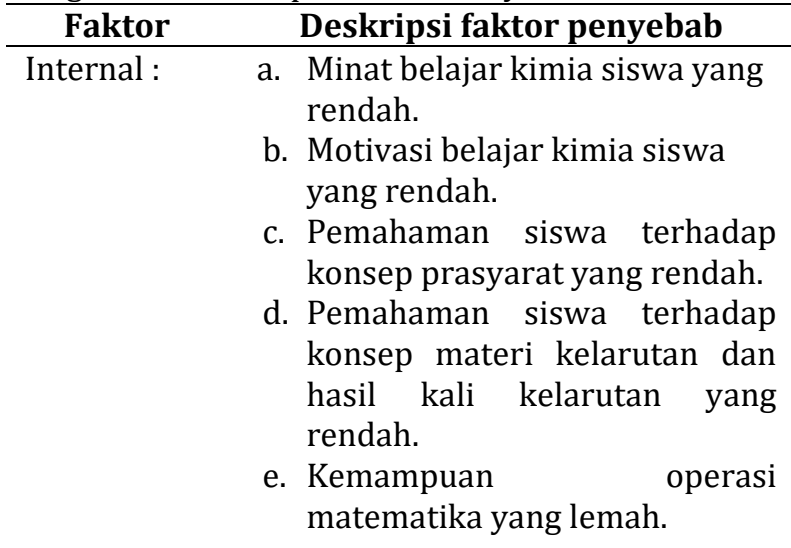

Eksternal: a. Pengaruh negatif dari teman sebaya.

b. Metode mengajar yang diterapkan guru. 


\section{PEMBAHASAN}

Berdasarkan hasil penelitian yang telah dipaparkan, diketahui bahwa siswa kelas XII IPA SMAN 1 Sukasada mengalami kesulitan pada semua indikator materi kelarutan dan hasil kali kelarutan. Hasil penelitian ini sejalan dengan penelitian yang dilakukan oleh Ulfa (2016) yang menunjukkan bahwa siswa mengalami kesulitan belajar pada semua indikator yang diujikan.

Rentangan kesulitan belajar yang dialami berkisar antara cukup sulit sampai sangat sulit. Pada penelitian ini ditemukan bahwa kesulitan belajar tertinggi terjadi pada indikator menyebutkan faktorfaktor yang mempengaruhi kelarutan suatu zat dan menjelaskan pengaruh penambahan ion senama dalam larutan dengan kategori sangat sulit, sedangkan kesulitan belajar terendah terjadi pada indikator menghubungkan tetapan hasil kali kelarutan dengan tingkat kelarutan atau pengendapannya termasuk kategori cukup sulit.

\section{Kesulitan menyebutkan faktor-faktor yang mempengaruhi kelarutan suatu zat}

Indikator ini tergolong sangat sulit dengan persentase kesulitan 92\%. Berdasarkan hasil analisis, siswa tidak cermat dalam membaca soal sehingga banyak yang keliru dalam memilih jawaban yang tepat. Butir soal tersebut membahas tentang faktor yang tidak mempengaruhi kelarutan pada zat padat di dalam air dan siswa banyak yang menjawab pengadukan. Padahal pengadukan merupakan salah satu faktor yang mempercepat kelarutan zat padat di dalam air, sebagaimana biasa dilakukan pada saat membuat minuman teh, kopi, atau susu. Hal ini menunjukkan siswa kurang memahami konsep kelarutan sehingga tidak dapat membedakan antara faktor kelarutan di dalam air dan gas.

\section{Kesulitan menjelaskan pengaruh penambahan ion senama dalam larutan}

Kesulitan ini tergolong sangat sulit dengan persentase kesulitan sebesar 96\%. Berdasarkan hasil analisis, hampir seluruh siswa menjawab salah soal yang berkaitan dengan pengaruh ion senama terhadap kelarutan. Hal ini menunjukkan bahwa siswa tidak memahami secara utuh konsep pengaruh ion senama terhadap kelarutan sehingga terkecoh dengan soal. Pemahaman siswa yang sangat rendah pada konsep pengaruh ion senama terhadap kelarutan dikarenakan rendahnya pemahaman siswa pada konsep kesetimbangan garam sukar larut. Konsep utama dalam mempelajari konsep pengaruh ion senama adalah prinsip Le Chatelier dalam kesetimbangan kimia. Jika siswa mengalami kesulitan dalam memahami konsep kesetimbangan kimia maka siswa juga akan mengalami kesulitan dalam memahami konsep ini.

\section{Kesulitan menentukan pH larutan dari harga Ksp atau kelarutannya}

Kesulitan ini tergolong sulit dengan persentase kesulitan sebesar 64,2\%. Berdasarkan hasil analisis, kesulitan siswa pada indikator ini terletak pada kesalahan siswa dalam menuliskan persamaan ionisasi. Banyak siswa yang masih keliru dalam menentukan ion positif dan ion negatif serta menentukan muatan dari ion-ion yang terurai, sehingga berdampak pada penulisan ungkapan Ksp. Kesalahan lain yang ditemukan adalah pada operasi matematika hubungan antara kelarutan dengan Ksp maupun $\mathrm{pH}$. Beberapa siswa yang paham dalam menghitung nilai Ksp jika diketahui pH tidak memahami cara menghitung kelarutan jika diketahui $\mathrm{pH}$ larutan. Rendahnya pemahaman siswa pada konsep hubungan $\mathrm{pH}$ larutan dengan kelarutan dikarenakan siswa belum memahami aplikasi atau penggunaan rumus dalam menentukan $\mathrm{pH}$ asam atau basa. Siswa juga kesulitan menghitung dengan menggunakan operasi bilangan akar pangkat, padahal dalam mempelajari kimia hal ini sangat penting karena pengetahuan matematika siswa dibutuhkan apabila soal diaplikasikan dengan angka. Kesulitan siswa pada indikator ini disebabkan oleh kurangnya pemahaman siswa pada konsep menghubungkan harga Ksp dengan pH dan konsep dasar kimia seperti persamaan reaksi dan konsep asam basa serta lemahnya kemampuan matematika siswa.

\section{Kesulitan memperkirakan terbentuknya endapan berdasarkan harga Ksp}

Kesulitan ini tergolong sulit dengan persentase kesulitan sebesar 71,3\%. Berdasarkan hasil analisis, siswa tidak memahami konsep secara utuh berkaitan dengan konsentrasi ion-ion dari pencampuran dua larutan. Hal ini ditunjukan oleh jawaban tes siswa yang salah dalam mencari konsentrasi ion dari $\mathrm{Ag}^{+}$dan $\mathrm{Cl}^{-}$, sehingga salah dalam menentukan harga Qc. Kesalahan lain yang ditemukan adalah masih terdapat siswa yang tidak memahami perbedaan antara Ksp dan Qc, siswa juga menganggap bahwa endapan akan tercapai apabila nilai Ksp lebih besar dari nilai Qc. Siswa juga kesulitan dalam mengaplikasikan pengetahuan matematika, hal ini ditunjukan oleh jawaban tes siswa yang masih keliru dalam menghitung, seperti siswa yang mendapatkan hasil yang salah padahal langkah pengerjaannya sudah benar. Kesulitan siswa pada konsep ini dikarenakan oleh kurangnya pemahaman siswa pada konsep prasyarat seperti kesetimbangan kimia.

\section{Minat belajar kimia siswa rendah}


Siswa memang tidak memiliki minat untuk belajar kimia sehingga menyebabkan siswa malas belajar dan beranggapan bahwa materi kelarutan dan hasil kali kelarutan sulit untuk dipelajari. Hal ini juga dikemukakan oleh guru kimia yang menyebutkan bahwa kemauan siswa untuk mempelajari kelarutan dan hasil kali kelarutan sangat kurang dan siswa tidak pernah melatih diri serta melakukan persiapan sebelum pembelajaran kimia di sekolah berlangsung.

\section{Motivasi belajar kimia siswa rendah}

Siswa cenderung belajar ketika ada ulangan saja. Selain itu, keingintahuan siswa pada materi kelarutan dan hasil kali kelarutan sangat rendah. Beberapa siswa mengaku apabila masih ada materi yang belum dipahami hanya bertanya kepada teman, namun tidak bertanya langsung kepada guru karena takut ditanyakan kembali oleh guru. Hal serupa juga dikemukakan oleh guru, ketika guru bertanya mengenai materi yang belum dipahami di awal pembelajaran, kebanyakan siswa cenderung diam dan tidak merespons. Ketika guru bertanya mengenai materi yang belum dipahami di akhir pembelajaran, siswa juga bersikap pasif. Hal ini memengaruhi keberlangsungan selama proses pembelajaran.

\section{Pemahaman terhadap konsep prasyarat materi yang masih rendah}

Konsep kelarutan dan hasil kali kelarutan juga merupakan salah satu konsep kimia yang pemahamanannya berjenjang dan berurutan. Konsep dasar yang harus dipelajari siswa sebelum mempelajari kelarutan dan hasil kali kelarutan adalah konsep asam basa, kesetimbangan kimia, dan persamaan reaksi. Siswa akan kesulitan dalam mempelajari konsep kelarutan dan hasil kali kelarutan, apabila siswa belum tuntas dalam mempelajari konsep dasar asam basa dan kesetimbangan kimia. Jika suatu materi yang dipelajari siswa memerlukan penguasaan materi lain sebagai prasyarat, maka siswa harus menguasai materi prasyarat tersebut sebelum siswa melanjutkan materi yang berikutnya (Suwarto, 2013). Dengan demikian, lemahnya pemahaman siswa terhadap konsep-konsep pada materi kelarutan dan hasil kali kelarutan disebabkan siswa masih mengalami masalah yang berkaitan dengan konsepkonsep prasyarat yang meliputi konsep asam basa, konsep kestimbangan kimia, dan persamaan reaksi.

Pemahaman mengenai konsep prasyarat pembelajaran sejalan dengan teori belajar kognitif yang dikemukakan oleh Piaget. Teori belajar kognitif Piaget menyatakan bahwa, proses asimilasi akan terjadi jika suatu informasi atau pengalaman baru dapat disesuaikan dengan kerangka kognitif yang sudah ada di benak siswa, sedangkan akomodasi akan terjadi jika perubahan atau pengembangan kerangka kognitif yang sudah ada dibenak siswa agar sesuai dengan pengalaman yang baru dialami. Pengetahuan tidak dapat dipindahkan dengan begitu saja dari guru ke siswa. Setiap siswa harus membangun pengetahuan sendiri-sendiri berdasrkan pengetahuan atau pengalaman lama yang sudah dimiliki atau pernah dialami siswa.

\section{Pemahaman siswa terhadap konsep kelarutan dan hasil kali kelarutan yang masih rendah}

Hal ini dikarenakan pemaknaan konsep siswa yang masih rendah, siswa cenderung menghafal materi tanpa memhaminya secara utuh sehingga menyebabkan materi yang dipelajari akan lebih cepat terlupakan. Seperti yang dikemukakan oleh Harefa (2013), bahan subjek yang dipelajari siswa haruslah bermakna. Pembelajaran bermakna terjadi apabila siswa dapat menghubungkan fenomena baru ke dalam struktur pengetahuan mereka. Pembelajaran bermakna juga merupakan pembelajaran yang menyenangkan yang memiliki keunggulan dalam meraup segenap informasi secara utuh sehingga dapat meningkatkan kemampuan siswa (Purnomo, 2009).

\section{Kemampuan matematika siswa masih rendah}

Berdasarkan hasil wawancara, Siswa masih kesulitan dalam aspek perhitungan desimal dan operasi bilangan akar berpangkat. Informasi ini dibenarkan oleh guru dengan memberikan pernyataan bahwa kemampuan siswa dalam matematika masih sangat kurang. Hal ini sejalan dengan penelitian Rengganis (2010) yang menyatakan bahwa kebanyakan siswa yang mempelajari kimia mengalami kesulitan pada aspek matematika. Pemahaman ilmu kimia tidak bisa lepas dari kemampuan matematika yaitu kemampuan berhitung. Seperti pendapat Bell (dalam Merdekawati, 2013) yang menyatakan bahwa tiap bagian dari kimia selalu membutuhkan keterampilan matematika sebagai contoh penentuan konsentrasi, perhitungan mol dan $\mathrm{pH}$. Akan tetapi, siswa masih banyak yang mengalami permasalahan dalam aspek matematika. Hasil penelitian ini serupa dengan pendapat Arifin (dalam Chaerunisa, et al. 2016) yang mengatakan bahwa kebanyakan siswa yang kurang memahami rumusan perhitungan kimia karena siswa tidak mengetahui dasar-dasar matematika dengan baik.

\section{Pengaruh negatif dari teman sebaya}


Teman sebaya memiliki pengaruh yang besar dalam perkembangan siswa. Pengaruh negatif yang dimaksudkan adalah teman sebangku terkadang mengajak membicarakan hal lain pada saat pembelajaran berlangsung. Hal ini membuat siswa merasa tidak berkonsentrasi selama pembelajaran. Informasi tersebut juga dibenarkan oleh guru, bahwasannya siswa sering mengobrol dan bercanda pada saat pembelajaran berlangsung. Hal yang sama ditemukan oleh Windari (2016), yaitu siswa cenderung bermain-main atau bercanda dengan temannya di kelas ketika diberikan waktu untuk menyelesaikan soal-soal yang diberikan oleh guru. Pengaruh lingkungan terhadap hasil belajar siswa diawali dari pergaulan dengan teman.

Teman sebaya tidak hanya memiliki pengaruh negatif, namun juga memiliki pengaruh positif. Berdasarkan hasil wawancara, pengaruh teman sebaya ini juga memberikan pengaruh yang positif. Pengaruh positif dari teman sebaya ditunjukkan dari hasil wawancara siswa yang menyatakan bahwa mereka lebih senang bertanya kepada teman apabila ada materi pelajaran yang belum dipahami. Selain itu siswa juga mengadakan kerja kelompok untuk belajar bersama dan menyelesaikan tugas-tugas yang berkaitan dengan materi kimia.

\section{Metode mengajar yang diterapkan guru}

Berdasarkan hasil wawancara, siswa yang termasuk ke dalam kelompok siswa berkesulitan belajar sedang dan tinggi tidak menyukai cara mengajar guru. Oleh karena itu penggunaan metode mengajar hendaknya divariasikan sehingga mampu mengakomodasi kemampuan dan gaya belajar siswa yang berbeda-beda dan siswa tidak merasa cepat bosan. Metode mengajar diharapkan dapat menciptakan interaksi belajar mengajar antara siswa dengan guru dalam proses pembelajaran. Dengan pemilihan metode yang baik dan tepat guna serta tepat sasaran akan semakin menciptakan interaksi edukatif yang semakin baik pula. Penggunaan metode mengajar yang bervariasi akan menumbuhkan semangat partisipatif siswa, mengurangi kebosanan, menumbuhkan ketertarikan dan memberikan kesempatan kepada siswa untuk menentukan pilihan yang tepat dengan gaya belajar masing-masing. Sejalan dengan pernyataan Mujiman (2009), bahwa penetapan metode mengajar erat kaitannya dengan pengembangan belajar siswa. Metode yang tepat akan menumbuhkan motivasi belajar yang baik dan bila disertai dengan kemampuan refleksi yang baik maka akan mendorong siswa untuk belajar.

\section{SIMPULAN DAN SARAN}

Berdasarkan hasil penelitian dan pemabahasan, dapat disimpulkan bahwa bentuk kesulitan belajar yang dialami siswa adalah pemahaman materi prasyarat kelarutan, kesalahan dalam menuliskan ionisasi garam, kesalahan penggunaan rumus Ksp, pemahaman siswa mengenai konsep asam basa, pemahaman siswa mengenai konsep kesetimbangan kimia, pemahaman siswa pada penulisan persamaan reaksi, kemampuan operasi matematika, dan kurang teliti dalam mengerjakan soal. Dan faktor-faktor penyebab kesulitan belajar siswa dalam mehamai materi kelarutan dan hasil kali kelarutan mencakup faktor internal dan faktor eksternal. Faktor internal meliputi pemahaman siswa pada materi kelarutan dan hasil kali kelarutan yang rendah, pemahaman siswa pada konsep prasyarat kelarutan dan hasil kali kelarutan yang rendah, kemampuan operasi matematika yang lemah, minat belajar kimia yang rendah, dan motivasi belajar kimia yang rendah. Faktor eksternal meliputi pengaruh teman sebaya dan cara mengajar guru.

Berdasarkan hasil yang telah dicapai pada penelitian ini, saran yang dapat diberikan adalah siswa diharapkan dapat lebih meningkatkan motivasi dan minat belajar kimia sehingga berpartisipasi aktif dalam pembelajaran dan prestasi belajar dapat meningkat. Dan guru diharapkan dapat meningkatkan minat dan motivasi belajar kimia siswa dengan menerapkan metode mengajar yang bervariasi, agar siswa lebih tertarik dalam mengikuti pembelajaran kimia.

\section{DAFTAR RUJUKAN}

Arianto, A., Saputra, R \& Sartika, R.P. 2016. Deskripsi Pemahaman Konsep Siswa Pada Materi Kelarutan dan Hasil Kali Kelarutan Kelas IX IPA SMA. Jurnnal Pendidikan Kimia, 5 (1).

Abdurrahman, M. 2012. Anak Berkesulitan Belajar. Jakarta: PT Rineka Cipta

Arikunto, S. 2002. Metodologi Penelitian Suatu Pendekatan Proposal. Jakarta: Rineka Cipta.

Arikunto,S. 2010. Prosedur Penelitian. Jakarta: Rineka Cipta.

Arikunto, S. 2013. Dasar-Dasar Evaluasi Pendidikan. Jakarta: Bumi Aksara.

Baharuddin \& Nur, E. 2012. Teori Belajar dan Pembelajaran. Jogjakarta: AR-Ruzz Media. 
Vol. 3, No. 1, Tahun 2019 , pp. 7-16

BSNP. 2006. Permendiknas RI No. 22 Tahun 2006 tentang Standar Isi Untuk Satuan Pendidikan Dasar dan Menengah. Jakarta: Badan Standar Nasional Pendidikan.

Chandrasegaran, A. L., Treagust, D. F., Mocerino, M. 2007. The Development of a Two-tier Multiple-Choice Diagnostic Instrument for Evaluating Secondary School Students' Ability to Describe and Explain Chemical Reactions Using Mutiple Levels of Representation. Chemistry Education Research and Practice, 8(3) : 293 - 307.

Chang, R. 2010. Chemistry (Tenth edition). New York: McGraw-Hill.

Danar, V. F. 2012. Hubungan Antara Motivasi Belajar Intrinsik dan Ekstrinsik Siswa dengan Prestasi Belajar Siswa Kelas X Kompetensi Keahlian Teknik Audio Video SMK Ma'arif 1 Wates. Skripsi Universitas Negeri Yogyakarta.

Dalyono, M. 2007. Psikologi Pendidikan. Jakarta: PT Rineka Cipta.

Dimyati \& Mudjiono. 2006. Belajar dan Pembelajaran. Jakarta: Rineka Cipta

Harefa, A. 0. 2013. Penerapan Teori Pembelajaran Ausebel dalam Pembelajaran. Warta Dharmawangsa. 36: 43-55.

Hidayah, N. 2013. Analisis Pemahaman Konsep Siswa pada Materi Kelarutan dan Hasil Kali Kelarutan. Jurnal Universitas Negeri Semarang.

Kean, E. \& Middlecamp, C. 1985. Panduan Belajar Kimia Dasar. Jakarta: Gramedia.

Merdekawati, K. 2013. Pengaruh Kemampuan Matematik terhadap Prestasi Belajar Kimia. Jurnal Inovasi dan Kewirausahaan. 2(1) 26-31.

Moleong, L. J. 2016. Metode Penelitian Kualitatif. Bandung: PT Rosdakarya.

Muhson, A. 2006. Teknik Analisis Kualitatif. Universitas Negeri Yogyakarta. Yogyakarta.

Mujiman, H. 2009. Manajemen Pelatihan Berbasis Belajar Mandiri. Yogyakarta: Pustaka Pelajar.

Mulyadi. 2010. Diagnosis Kesulitan Belajar \& Bimbingan Terhadap Kesulitan Belajar Khusus. Yogyakarta: Nuha Litera.

Nabilah, A., Yayuk, \& Laksmiwati, D. 2018. Analisis Tingkat Pemahaman Konsep Siswa Kelas XI IPA SMAN 3 Mataram Menggunakan One Tier dan Two Tier Test Materi Kelarutan dan Hasil Kali Kelarutan. Jurnal Pijar MIPA, 8(2): 64-69.

Nakhleh, M. 1992. Why Some Students Don't Learn Chemistry: Chemical Misconceptions. Journal of Chemical Education. 69(3): 191-196.

Onder, I., \& Geban, 0. 2006. The Effect of Conceptual Change Text Oriented Instruction on Students Understanding of The Solubility Equilibrium Concept. Journal of Education.

Purba, M \& Sunardi. 2012. Kimia Untuk SMA/MA Kelas XI. Jakarta: PT Gelora Aksara Pratama.

Purnomo, W. 2009. CPD dan IT dalam Mendukung Terciptanya Pembelajaran Bermakna Menyongsong Era Imajinasi. Makalah disajikan dalam Seminar Nasional Klub Guru. Politeknik Negeri Malang

Rengganis. 2010. Analisis Kemampuan Penyelesaian Soal Kimia Level Simbolik Secara Sistematik oleh Siswa Kelas X Pada Materi Pokok Stoikiometri. Jurnal Kimia dan Pendidikan. 3(1).

Ristiyani, E \& Bahariah, E.V. 2016. Analisis Kesulitan Belajar Kimia Siswa di SMAN X Kota Tangerang Selatan. Jurnal Penelitian dan Pembelajaran IPA, 2(1): 18-29.

Rumansyah, Y. 2002. Penerapan Metode Latihan Berstruktur dalam Meningkatkan Pemahaman Siswa Terhadap Konsep Persamaan Kimia. Jurnal Pendidikan dan Kebudayaan. 35: 172.

Sastrika, I.A.K., Sadia, I.W \& Muderawan, I.W. 2013. Pengaruh Model Pembelajaran Berbasis Proyek Terhadap Pemahaman Konsep Kimia dan Keterampilan Berpikir Kritis. e-Journal Program Pascasarjana Univesitas Pendidikan Ganesha, 3:1-10.

Sapuroh, S. 2010. Analisis Kesulitan Belajar Siswa Dalam Memahami Konsep Biologi Pada Konsep Monera di MAN Serpong Tanggerang. Skripsi Universitas Islam Negeri Syarif Hydayatullah.

Siregar, S. 2011. Statistika Deskriptif Untuk Penelitian: Dilengkapi Perhitungan Manual dan Aplikasi SPSS Versi 17. Jakarta: PT. Raja Grafindo Persada. 
Vol. 3, No. 1, Tahun 2019 , pp. 7-16

Slameto. 2003. Belajar dan Faktor-faktor yang Mempengaruhinya. Jakarta: Rineka Cipta.

Sudijono, A. 2011. Pengantar Evaluasi Pendidikan. Jakarta: Rajawali Pers.

Sugiyono. 2009. Metode Penelitian Bisnis (Pendekatan Kuantitatif, Kualitatif, dan R\&D). Bandung: Alfabeta.

Sugiyono. 2014. Metode Penelitian Kuantitatif, Kualitatif, dan R\&D. Bandung: alfabeta.

Suwarto. 2013. Belajar Tuntas, Miskonsepsi, dan Kesulitan Belajar. Jurnal Pendidikan. 22(1): 85 - 95.

Ulfa, T., Rusman \& Khaldun, I. 2016. Analisa Kesluitan Pemahaman Konsep Kelarutan dan Hasil Kali Kelarutan Pada Siswa SMA Inshafuddin Tahun Ajaran 2015/2016. Jurnal Ilmiah Mahasiswa Pendidikan Kimia, 1(4).

Vyandari, A., Pramoko, S., \& Latifah. 2012. Analisis Miskonsepsi Siswa Terhadap Materi Kelarutan dan Hasil Kali Kelarutan Dengan Two-tier Diagnostic Instrument. Jurnal Inovasi Pendidikan Kimia, 6(1): 852- 861

Windari, N. K. A. 2016. Analisis Kesulitan Siswa dalam Menyelesaikan Soal-soal Kelarutan dan Hasil Kali Kelarutan di SMA Negeri 1 Gianyar. Skripsi Universitas Pendidikan Ganesha. 